\title{
Fuentes documentales para la historia de Melilla: La Vicaría de Africa del Archivo Diocesano de Málaga
}

\author{
Jesús F. Salafranca Ortega
}

Dentro de la Sección Histórica del Archivo Diocesano de Málaga se encuentra el fondo documental de la Vicaría de Africa. Una de las partes fundamentales de este fondo está dedicada a Melilla y constituye, sin duda, una fuente insustituible para el conocimiento de la historia de la Ciudad.

Vicaría de Africa

Comprende tres secciones:
a) Sección Alhucemas.
b) Sección Vélez de la Gomera.
c) Sección Melilla.

Se halla ubicada en el estante $2 .^{\circ}$ derecha de los cinco que comprende la Sección Histórica del Archivo Diocesano. Toda la documentación de esta Sección al igual que la totalidad de las que componen el Archivo, se halla dividida en cajas que van numeradas o señalizadas por orden alfabético y con la denominación genérica de $p$ (pueblos) a diferencia de las de la ciudad de Málaga que van denominadas con la letra $c$ (capital).

\section{Sección de Alhucemas}

Consta de 10 cajas de documentos desde 1678 hasta 1931. Como no son el objeto fundamental de la investigación no los he estudiado muy a fondo.

Las cajas de esta Sección son las únicas de todo el Archivo que van denominadas por orden alfabético. 
Sección de Vélez de la Gomera

Consta sólo de dos cajas con documentos desde 1571 hasta 1817. Al igual que los de Alhucenas poco estudiados y por la misma razón.

Sección de Melilla

Estudiada a fondo, comprende documentos desde 1535 hasta 1968 , siendo los más interesantes lógicamente los anteriores al siglo XX.

Conviene destacar que hasta 1858 toda la documentación corresponde a la Iglesia de la Inmaculada Concepción y, a partir de esta fecha, aparece también, la del Sagrado Corazón de Jesús.

Relación de documentos de Melilla, Alhucemas y Vélez de la Gomera que se encuentran en la Vicaria de Africa del Archivo Diocesano (Sección Histórica) de Málaga.

\section{a) Alhucemas}

Caja p A de Alhucemas. - Contiene:

Bautismos desde 1678 hasta 1931.

Caja p $B$ de Alhucemas. - Contiene:

Matrimonios desde 1679 hasta 1924.

Caja p $C$ de Alhucemas. - Contiene:

Defunciones desde 1682 hasta 1931.

Caja p $D$ de Alhucemas. - Contiene:

Bulables.

Caja p E de Alhucemas.- Contiene:

Hermandades.

Caja p $F$ de Alhucemas. - Contiene:

Padrones.

Caja p G de Alhucemas.- Contiene:

Fábrica.

Caja $p H$ de Alhucemas.- Contiene:

Varios.

Caja p I de Alhucemas.- Contiene:

Varios.

Caja p $J$ de Alhucemas.- Contiene:

Varios.

b) Vélez de la Gomera

Caja p 1 de Vélez de la Gomera.- Contiene:

Bautismos desde 1571 hasta 1882 . 
Caja p 2 de Vélez de la Gomera.- Contiene:

Matrimonios y Defunciones desde 1688 hasta 1817.

c) Melilla

Caja $p 3$ de Melilla.- Contiene:

Libro n. 1 de Bautismos, desde 4 de julio 1535 hasta 26 diciembre 1574.

Libro n. 2 de Bautismos, desde 6 enero 1575 hasta 9 diciembre 1586.

Libro $\mathrm{n}^{\circ} 3$ de Bautismos, desde 18 enero 1587 hasta 8 diciembre 1617.

Libro n. $^{\circ} 4$ de Bautismos, desde 14 enero 1618 hasta 21 diciembre 1640.

Caja p 4 de Melilla.- Contiene:

Libro n. 5 de Bautismos, desde 2 enero 1641 hasta 10 noviembre 1664.

Libro n. ${ }^{\circ} 6$ de Bautismos, desde 16 noviembre 1664 hasta 27 septiembre 1694.

Libro n. 7 de Bautismos, desde 29 septiembre 1694 hasta 2 marzo 1718 (1).

Caja $p 5$ de Melilla.- Contiene:

Libro n. ${ }^{\circ} 8$ de Bautismos, desde 17 abril 1718 hasta 25 enero 1737 (1).

Libro n. ${ }^{\circ} 9$ de Bautismos, desde 27 de enero 1737 hasta 26 septiembre 1763 (1).

Libro n. ${ }^{\circ} 10$ de Bautismos, desde 10 octubre 1763 hasta 29 septiembre 1777 (1).

Caja p 6 de Melilla. - Contiene:

Libro n. 11 de Bautismos, desde 27 octubre 1777 hasta 11 junio 1811 (1).

Libro n. 12 de Bautismos, desde 12 junio 1811 hasta 10 junio 1850 (1).

Libro n. 13 de Bautismos, desde 24 julio 1850 hasta 2 febrero 1866 (1).

Caja $p 7$ de Melilla.- Contiene:

Minutas de Bautismo desde 1907 hasta 1913.

Caja p 8 de Melilla.- Contiene:

Minutas de Bautismo desde 1914 hasta 1916.

Caja $p 9$ de Melilla.- Contiene:

Minutas de Bautismo desde 1916 hasta 1917.

Caja p 10 de Melilla.- Contiene:

Minutas de Bautismo desde 1917 hasta 1919.

Caja $p 11$ de Melilla.- Contiene:

Minutas de Bautismo desde 1919 hasta 1920.

Caja p 12 de Melilla. - Contiene:

Minutas de Bautismo desde 1920 hasta 1922.

Caja p 13 de Melilla.- Contiene:

Minutas de Bautismo desde 1922 hasta 1924.

Caja p 14 de Melllla.- Contiene:

Minutas de Bautismo desde 1924 hasta 1926.

Caja p 15 de Melilla.- Contiene:

Minutas de Bautisno desde 1926 hasta 1928.

(1) Contiene indice alfabeto-cronológico, habiéndose hecho el orden alfabético por el nombre de pila. 
Caja p 16 de Melilla.- Contiene:

Minutas de Bautismo desde 1928 hasta 1929.

Caja p 17 de Melilla.- Contiene:

Minutas de Bautismo desde 1930 hasta 1931.

Caja $p 18$ de Melilla.- Contiene:

Minutas de Bautismo desde 1931 hasta 1932.

Caja p 19 de Melilla.- Contiene:

Minutas de Bautismo desde 1932 hasta 1934.

Caja p 20 de Melilla.- Contiene:

Minutas de Bautismo desde 1934 hasta 1935.

Caja p 21 de Melilla.- Contiene:

Minutas de Bautismo desde 1936 hasta 1937.

Caja p 22 de Melilla.- Contiene:

Minutas de Bautismo desde 1937 hasta 1939.

Caja p 23 de Melilla.- Contiene:

Minutas de Bautismo desde 1937 hasta 1940.

Caja p 24 de Melilla.- Contiene:

Minutas de Bautismo desde 1939 hasta 1941.

Caja p 25 de Melilla.- Contiene:

Minutas de Bautismo desde 1940 hasta 1942.

Caja p 26 de Melilla.- Contiene:

Minutas de Bautismo desde 1942 hasta 1944.

Caja p 27 de Melilla.- Contiene:

Minutas de Bautismo desde 1944 hasta 1947.

Caja p 28 de Melilla.- Contiene:

Minutas de Bautismo desde 1947 hasta 1953.

Caja p 29 de Melilla.- Contiene:

Minutas de Bautismo desde 1953 hasta 1957.

Caja p 30 de Melilla.- Contiene:

Minutas de Bautismo desde 1957 hasta 1961.

Caja $p 31$ de Melilla.- Contiene:

Minutas de Bautismo desde 1961 hasta 1966.

Caja $p 32$ de Melilla.- Contiene:

Está vacía.

Caja p 33 de Melilla. - Contiene:

Libro $\mathrm{n}^{\circ} 1$ de Matrimonios desde 26 noviembre 1565 hasta 16 noviembre 1586.

Libro $n^{\circ} 2$ y 3 de Matrimonios desde 1 febrero 1587 hasta 27 marzo 1662 (2).

Libro n. 4 de Matrimonios desde 25 junio 1662 hasta 6 noviembre 1742 .

Caja $p 34$ de Melilla.- Contiene:

Libro n. 5 de Matrimonos desde 24 enero 1743 hasta 2 mayo 1867 (1). Libro n. ${ }^{\circ} 6$ de Matrimonios desde 4 mayo 1867 hasta 7 septiembre 1902 (1)

(2) Contiene indice cronológico. 
Caja $p 35$ de Melilla.- Contiene:

Minutas de Matrimonios desde 1922 hasta 1930.

Caja p 36 de Melilla.- Contiene:

Minutas de Matrimonios desde 1932 hasta 1937.

Caja $p 37$ de Melilla.- Contiene:

Minutas de Matrimonios desde 1936 hasta 1937.

Caja $p 38$ de Melilla.- Contiene:

Minutas de Matrimonios desde 1937 hasta 1944.

Caja $p 39$ de Melilla.- Contiene:

Minutas de Matrimonios desde 1952 hasta 1966.

Caja p. 40 de Melilla.- Contiene:

Libro n. ${ }^{\circ} 1$ de Defunciones desde 14 marzo 1632 hasta 29 diciembre 1658 (3).

Libro n. 2 de Defunciones desde 17 enero 1659 hasta 29 diciembre 1696 (1) (3).

Libro n. 3 de Defunciones desde 15 enero 1697 hasta 19 octubre 1717.

Caja p. 41 de Melilla.- Contiene:

Libro n. ${ }^{\circ} 4$ de Defunciones desde 28 diciembre 1717 hasta 18 agosto 1727 (1).

Libro n. 5 de Defunciones desde 18 agosto 1727 hasta 8 noviembre 1752 (1).

Libro $\mathrm{n}^{\circ} 6$ de Defunciones desde 9 noviembre 1752 hasta 29 diciembre 1773 (1).

Caja p 42 de Melilla.- Contiene:

Libro n. ${ }^{\circ} 7$ de Defunciones desde 4 enero 1774 hasta 9 noviembre 1802 (1).

Caja p 43 de Melilla.- Contiene:

Libro n. 8 de Defunciones desde 11 noviembre 1802 hasta 19 octubre 1852 (1). Caja p 44 de Melilla.- Contiene:

Libro n. 9 de Defunciones desde 31 octubre 1852 hasta 21 marzo 1863 (1).

Libro $n .{ }^{\circ} 10$ de Defunciones desde 28 marzo 1863 hasta 8 diciembre 1880 (1).

Libro $n .^{\circ} 11$ de Defunciones desde 19 diciembre 1880 hasta 20 mayo 1895 (1).

Caja p 45 de Melilla. - Contiene:

Minutas de Defunciones desde 1916 hasta 1930.

Caja $p 46$ de Melilla.- Contiene:

Minutas de Defunciones desde 1932 hasta 1942.

Caja p 47 de Melilla.- Contiene:

Minutas de Defunciones desde 1943 hasta 1945.

Caja $p 48$ de Melilla.- Contiene:

Minutas de Defunciones desde 1948 hasta 1952.

Caja p 49 de Melilla.- Contiene:

Minutas de Defunciones desde 1952 hasta 1968.

Caja p 50 de Melilla.- Contiene:

Documentos varios del siglo XX y algunos oficios del XIX entre los que destacan:

- Hospitales: Oficios e inventarios.

-Documentos en espera del interesado: hasta 1970.

-Cartas-órdenes: hasta 1973.

-Documentos pendientes: hasta 1941.

(3) Contiene relación de misas que se han dicho por el alma de cada difunto y su precio. 
Caja p 51 de Melilla.- Contiene:

Documentos varios del siglo XX y uno del XIX.

Caja $p 52$ de Melilla.- Contiene:

Censo de Presidiarios de 1853 (4).

Censo de Presidiarios de 1855 (4).

Censo de Presidiarios de 1856 (4).

Censo de Presidiarios de 1864.

Censo de Presidiarios de 1865.

Censo de Presidiarios de 1866.

Censo de Presidiarios de 1867.

Censo de Presidiarios de 1868.

Censo de Presidiarios de 1870.

Censo de Presidiarios de 1871.

Padrón de la Guarnición y de Presidiarios de 1861.

Inventario de imágenes, ornatos y alhajas de la Iglesia de 1857.

Inventario de imágenes, ornatos y alhajas de la Iglesia de 1859.

Inventario de imágenes, ornatos y alhajas de la Iglesia de 1862.

Inventario de imágenes, ornatos y alhajas de la Iglesia de 1864.

Inventario de imágenes, ornatos y alhajas de la Iglesia de 1870.

Inventario de imágenes, ornatos y alhajas de la Iglesia de 1873 (5).

Inventario de imágenes, ornatos y alhajas de la Iglesia de 1877.

Inventario de imágenes, ornatos y alhajas de la Iglesia de 1881.

Documentos varios del año 1933.

Documentos varios del año 1936.

Varios testamentos y misas de los siglos XVI, XVII y XVIII.

Caja p 53 de Melilla.- Contiene:

Libro de Misas, memorias y fundaciones desde 1733 hasta 1842.

Caja p 54 de Melilla.- Contiene:

Carpeta epigrafe: cementerio.- Ordenes de enterramientos o exhumaciones de los siglos XIX y XX.

Carpeta epígrafe: culto.- De los siglos XIX y XX.

Carpeta epígrafe: acólitos y sacristanes. - De los siglos XIX y XX.

Carpeta epígrafe: oficios varios.- De los siglos XIX y XX.

Carpeta epígrafe: personal de la parroquia. - De los siglos XIX y XX.

Carpeta epígrafe: haberes. - Del siglo XIX.

Caja p 55 de Melilla.- Contiene:

Certificados bautismales y matrimoniales de los siglos XIX y XX.

Censo parroquial de 1882 (6).

(4) En el censo se incluyen los confinados que tienen su familia viviendo en Melilla. El objeto del censo es saber los presos que tienen obligación de cumplir el Precepto Pascual, lo que nos priva de conocer si había presos no católicos.

(5) En este año hay dos inventarios distintos.

(6) Parcialmente destruido. 
Censo parroquial de 1883 (6).

Censo parroquial de 1884 (6).

Censo parroquial de 1885 (6).

Censo parroquial de 1886 (6).

Censo parroquial de 1887 (6).

Censo parroquial de 1888 (6).

Censo parroquial de 1889 (6).

Censo parroquial de 1890 (6).

Censo de presidiarios de 1869.

Libro de nacimientos de 1913 (7).

Caja p 56 de Melilla.- Contiene:

Documentos varios del siglo XX.

Caja p 57 de Melilla.- Contiene:

Documentos varios del siglo $\mathbf{X X}$.

(7) Prácticamente destruido por la humedad. 